\title{
Bilateral and Multilateral Approach of the United States and China Towards ASEAN
}

\author{
Irawan Jati \\ Department of International Relations, Universitas Islam \\ Indonesia
}

\begin{abstract}
The U.S. and China relations in Southeast Asia have been a long contesting history. It is no question that the U.S. and China are playing strategy to stronghold Southeast Asia for their gain. Both states seek greater influence by applying the multilateral and bilateral approach to ASEAN and its member states. In engaging to ASEAN, the U.S. and China joined ASEAN led multilateral forums such as the ASEAN Regional Forum (ARF) and ASEAN Plus Three. Traditionally, the U.S. and China already have bilateral diplomatic relations with all ASEAN member states. But it does not necessarily represent their deep commitment to the Southeast Asia region. Furthermore, ASEAN relations with the U.S. and China are overshadowed by the rivalry between the two major powers. The US increasing military tied with the Philippines and Thailand's strategic plan to acquire submarines from China are the recent development of rivalries between the two. Therefore, it is fascinating to examine how the US and China's bilateral and multilateral approaches affecting ASEAN and its member states policies. It is argued that ASEAN should maintain neutral performance in engaging with the U.S. and China. It also suggests that ASEAN member states should keep their 'community' identity to derogate the possible deterioration of the stability in the region.
\end{abstract}

Keywords: ASEAN, bilateral approach, China, multilateral approach, the U.S.

HubunganantaraAmerikaSerikat(A.S) dan Tiongkokdikawasan Asia Tenggara memiliki sejarah persaingan yang panjang. A.S dan Tiongkok memainkan strategi untuk menguasai Asia Tenggara demi kepentingan mereka. Kedua negara berusaha untuk mencapai pengaruh yang lebih luas dengan melakukan pendekatan multilateral dan bilateral pada ASEAN dan negara anggotanya. Dalam hubungaannya dengan ASEAN, A.S dan Tiongkok terlibat dalam forum multilateral ASEAN seperti ASEAN Regional Forum (ARF), dan ASEAN Plus Three. Secara tradisional, A.S dan Tiongkok telah memiliki hubungan diplomasi bilateral dengan negara anggota ASEAN. Namun hal tersebut belum menunjukkan komitmen utama mereka di kawasan Asia Tenggara. Lebih jauh lagi, hubungan ASEAN dengan A.S dan Tiongkok dibayangi oleh persaingan antar kedua negara besar tersebut. Peningkatan hubungan militer A.S dengan. Filipina dan rencana strategis Thailand untuk membeli kapal selam dari Tiongkok merupakan perkembagan teranyar dari persaingan antar kedua negara tersebut. Oleh karenaya, artikel ini akan menganalisis bagaimana pendekatan multilateral dan bilateral yang dilakukan oleh A.S dan Tiongkok mempengaruhi kebijakan ASEAN dan negara anggotanya. Argumen utama dalam artikel ini adalah ASEAN harus tetap mempertahankan netralitas dalam kebijakannya terhadap A.S dan Tiongkok. Artikel ini juga merekomendasikan, agar ASEAN dan negara ang gotanya tetap berpegang pada identitas 'komunitas' untuk menghindari kemungkinan perpecahan di kawasan.

Kata-kata kunci: ASEAN, pendekatan bilateral, pendekatan multilateral, Tiongkok (Cina), Amerika Serikat (A.S) 
Southeast Asia is a strategic region which attracts two of the world's major powers, the United States and China to contest for the supremacy (Majid 2012; Sutter 2005). The strategic aspects of Southeast Asia lie in its geographic position, its natural resources, and its people. These also become legitimate factors of US-China intense involvement in the region (Zubir 2004). The Malaka Strait of Southeast Asia is considered as one of most rapid sea trade route in the world. Annually, not less than 60.000 vessels crossing the straits (Zubir 2004). The massive vessels transit in the straits has brought an enormous economic potential for the countries in the region. Southeast Asian nations lay in a strategic area which connecting the Indian and Pacific Ocean. Underneath the oceans, the seabed and the islands, the region is rich in marine and mineral resources. ASEAN also has the huge potential for human capital. It is estimated that in 2012 ASEAN has 190 million people who are in middle class and it is predicted to be doubled in 2020 (Nielson 2015). This number is equal to $28 \%$ of ASEAN total population, which are larger than the US. ASEAN hosts the world's biggest Muslim population after the Middle East. Indonesia alone has more than 200 million Muslim which makes it the biggest in the world.

The U.S. and China relations in Southeast Asia have been a long contesting history. The US involvement in the region can be described as "too much" and "too little" attention (Mitchell 2008). After the World War II, US's containment foreign policy had sprung the Vietnam War. It was an intense involvement of the US considering the great scale of its military resources deployed. It was a clear evidence the of US "too much" involvement in a region. While in 1990's US paid little attention to the region and shifted its focus in the Middle East in securing its energy flow. On the other sides, China, which is geographically close to Southeast Asia, has taken more advantages in its relation to the region. Historically, China's relation to Southeast Asia nations cab traced back during the Ming Dynasty. In that period, China sent a large naval fleet to the region in order to collect the tribute for the emperor (Vaughn \& Morrison 2006). Since then, the Chinese had more engagement with the Southeast Asian.

The recent development of the US-China relations requires ASEAN competency in buffering those two major powers. To defuse the direct military and economic rivalries of those two major powers, ASEAN has established two prominent forums, the Regional Forums (ARF) and ASEAN Plus Three. However, these forums are not able to mollify China and the US indirect military and economic contest. Generally, U.S., China, ASEAN and its members only have two policy strategies: multilateral 
for ASEAN and bilateral for its members. ASEAN should be able to maintain its security community policy rather than to join any security pacts foreign major powers. Unfortunately, ASEAN members have more flexibility in orienting its defense and security policy. The absence of defense orientation and budget, encourage ASEAN member states to enjoy a "personalized" closely tied to US and China. This ambiguity may tear ASEAN apart and jeopardized the future of the region. For the US and China, bilateral relations would be the key interest to gain their strategic interests. Therefore, it is fascinating to examine how the US and China's bilateral and multilateral approaches affecting ASEAN and its member states policies. It is argued that ASEAN should play neutrality policy to maintain the stability of the region. ASEAN member states should keep promoting the community identity to deter the possibility of ASEAN disintegration caused by the split preference of its individual member. In presenting the idea, this paper is divided into three main sections. The first section briefly discusses the concept of multilateralism and bilateralism. The second section describes the U.S. and China multilateral and bilateral strategies towards Southeast Asia and ASEAN. The last section analyses ASEAN's position in responding the two major powers approaches. 


\section{Multilateralism and Bilateralism}

Viewing power contest of major powers from the perspective of multilateralism and bilateralism is not too common to find. Mostly, the analysis on security or strategy is based on various security theories under Realist, Constructivist, and Critical Studies. For Ruggie (1992), multilateralism is defined as an institutional form which coordinates relations among three or more states on the basis of "generalized" principles of conduct. These principles are the fundamental guide or ordering norms for the relations. Multilateralism has mattered much in international relations particularly after the formation of United Nations. The general assumption of multilateralism or institutionalism is that it believes in the capacity of the institution to alter states behaviors in which characterized by self-fulfillment of interests (Ruggie 1992). According to Donahue and Warin (2009), there are two strands of multilateralism. The first is hard multilateralism, where all members have equal and open information and involve independently in the decision-making process. The second is soft multilateralism, where the members have a certain degree of "reciprocal bilateralism". Reciprocal bilateralism happened when a major state or donor state demands favor of any aids that have been transferred to recipient state (Donahue \& Warin 2009). Donahue and Marin's work are a constructive approach to measure state's policy choice in determining the bilateral or multilateral strategy.

While bilateralism is defined as "differentiates relations case-by-case based principally on a priori particularistic grounds or situational exigencies" (Ruggie 1992). Even though bilateralism is limited in nature, it is a fundamental strategy of states to mitigate common interests. In ASEAN or any other international organization case, despite having multilateral aspect, its members have the opportunity to establish bilateral relations. In many cases, a bilateral relationship is an alternative option if the multilateral negotiation fails. However, this article is not intended to analyze the form of the U.S., and China multilateralism type neither hard or soft multilateralism. This article is intended to look at the multilateral and bilateral approach of the U.S., and China on ASEAN and in turn look at the way how ASEAN should respond.

\section{The U.S and China's Strategies of Influence in ASEAN}

The US-China contest of strategic influence in Southeast Asia can be assessed by their consistent approach to the region. To know more, it needs to look deeper into both strategic goals and how they able to attain the 
goals. The general picture of assumption of both major powers strategic goal is to acquire the dominant role in the region. The domination is not necessarily always having the tendency of military domination. It also does not require stated intention. It should be understood that the domination is the outcome of foreign policy efforts. In the same tone, state's domination is "actual instruments of influence and power" of a state (Stanley Foundation 2003).

\section{China's Approach}

Bilateral relations dominated China's approach after the World War II with its ASEAN neighbor. It was dictated by suspicion of ASEAN establishment as another form of US presence in Southeast Asia region (Hoon 1977). During this period, China was not fond of establishing peaceful diplomatic relations particularly with non-socialist or communist states like Indonesia, Malaysia, Singapore, Thailand and the Philippines. China found its interest matched with Northern Vietnam and Cambodia's left-wing political ideology. China's referenced in these states crystallized in the policy to sponsor the Vietcong and the Khmers. This has left Chinese aggressive impression for the most of Asian states, which in turn slowed the relations among Asian states. Nevertheless, China's policy orientation changed gradually after the Cold War. Right after the financial crisis in 1997, Southeast Asia and other East Asia states to involve China in a multilateral effort to consolidate economic potential of the region (MingTe \& Liu 2011).

The advancement of China's multilateralism is embossed by its four multilateral strategies including watching, engaging, circumventing, and shaping (Wuthnow, Li, \& Qi 2012). The watching strategy is an observation stage before China decides to engage in a multilateral institution. This strategy gives the time for China to assess the intention and benefit of the forum. When five Southeast Asian nations-initiated ASEAN, China saw ASEAN as the 'military alliance' aimed to serve 'U.S. imperialism' (Hoon 1977). This perspective gradually changed and so did the strategy. After a decade of wait and see, China seriously started to engage to ASEAN after the Cold War period.

China's post-Cold War engagement with ASEAN is characterized by four facets; the ideologically-free relations, the economic heavy territorial dispute in the South China Sea, and multilateral accords rather than bilateral (Kuik Cheng-Chwee 2005). In 1990's China quietly reassessed its concept of security and strategy to adjust to the strengthening of the US and Japan defense cooperation and heighten tension in Taiwan Straits (Thayer 2003). In 1998, China released its Defense White Paper, which introduced the 'New Security Concept' of China. There are four aspects 
of its 'New Security Concept', those are common security, comprehensive security, security cooperation, and sustainable security (Pattiradjawane \& Soebagjo 2015).

Meanwhile, China's circumventing strategy is an alternative strategy to 'escape' from the existing regime. Morse and Keohane use the term 'contested multilateralism' to describe this behavior. Contested multilateralism defined as 'the situation that results from the pursuit of strategies by states, multilateral organizations, and non-state actors to use multilateral institutions, existing or newly created, to challenge the rules, practices, or missions of existing multilateral institutions' (Morse \& Keohane 2014). Circumventing or contested multilateralism strategy enables China to find an alternative forum to serve its national interests. A good example of this strategy is China's support for ASEAN's Regional Comprehensive Economic Partnership (RCEP). China's support on RCEP is the strategy to challenge U.S.'s Trans-Pacific Partnership (TPP) grouping.

On the other hand, the shaping strategy is related to China's efforts in modifying or establishing new regulations or institutions. Despite, supporting the RCEP, China put its greatest attempt to re-establish its Silk Road legacy. The One Belt, One Road (OBOR) initiative outcasts China's economic and foreign policy orientation in the region. OBOR is a bold example of China's 'shaping' strategy since it takes the major role in establishing the new regime. For many analysts, OBOR would strengthen China's presence in Asia and Europe. In contrast with those analyses, Peter Cai argues that OBOR initiative is driven by domestic needs, as China struggles to eliminate its underdeveloped areas (Cai 2017). 


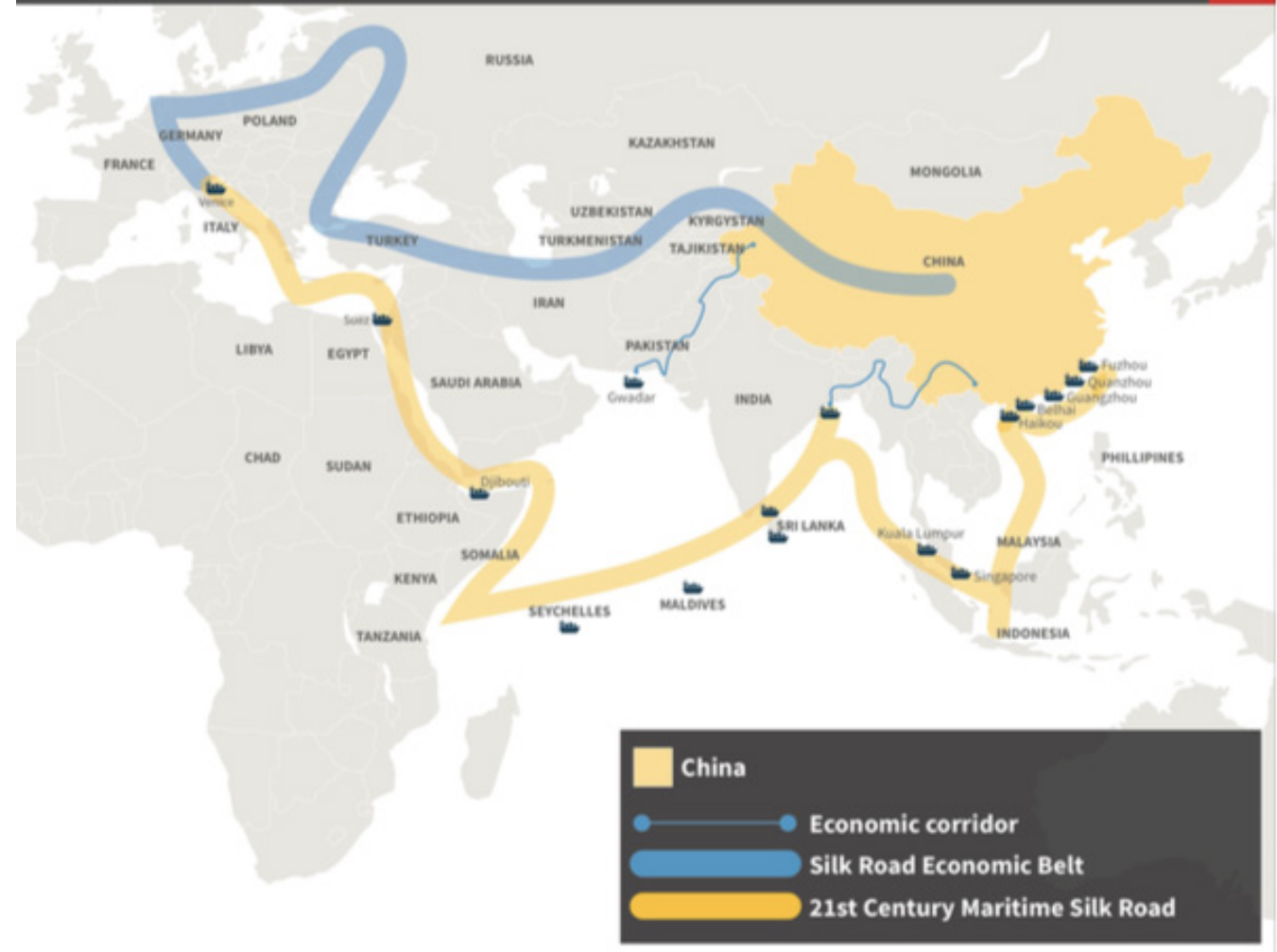

Picture 1. China's OBOR on map. (Cai, 2017)

There is no single literal identification of China's policy goals in Southeast Asia region. Analysts would argue verily based on their respected perspective and expertise. In the context of contesting with the US, one may say that China would play the cooperative card in dealing with the US. But for others, one of the policy goals is challenging US hegemonic role in the region. These 'dissenting opinions' may occur because of different standpoints. Generally, a Chinese analyst would see China's recent intense policy as friendly moves. But foreign analyst would see it as aggressive and hegemonic seeking. Take a look, for example, a view from Cao Yunhua on China's policy goals in Southeast Asia. He states that China's goals are summarized as follows (Yunhua 2013): (1) To protect overseas Chinese who live and work in this area and their property. (2) To advance China's presence and influence in this region. (3) To safeguard the integrity and unity of China's territorial lands and waters. (4) Working together with other great powers to develop a more justice, fair and reasonable regional 
order.

A competing perspective taken by foreign analyst would assert that China's policy goals in Southeast Asia are to neutralizing Taiwan's influence, to building a friendly image of China's presence and to overtake US's hegemonic position (Kurlantzick 2006). Another view relating to the motives of China's New Security Concept is China wants to endorse multipolar view in order to weaken US hegemony, it also a response to US advance alliances and China also wants to cast greater influence in Southeast Asia (Thayer 2003).

China's 'New Security Concept' is best described as a strategic policy shift from bilateral to multilateral. China introduces its security by combining the military, and economic approaches. With this comprehensive strategy, in 2013 China proposed to strengthen its relations with ASEAN with the $2+7$ proposal. The first 2 are considered as the basis of China-ASEAN future cooperation. China proposed that the cooperation should be on the basis of "strengthen(ing) strategic trust and consolidate good-neighborliness, and the key to deepening cooperation is to focus on economic development and expand mutual benefit" (Xinhua 2013). While the other seven are dominated by security projection and proposed to create a self-help system (Asia for Asians) by expelling the US as regional patron (Parameswaran 2013b). In the recent approach to get ASEAN's focus, Chinese Foreign Minister proposed 10 points proposals as to deepen its cooperation. As its previous $2+7$ proposal, these 10 proposals load of economic and security articulation. For instance, the fourth point encourages the establishment of international production capacity cooperation for the benefit of both parties. The ninth point proposes on the advancement of security cooperation (Ministry of Foreign Affairs of the People's Republic of China 2015).

\section{The U.S. Approach}

The United States is undisputedly a major (super) power not only in greater Asia Pacific but the world. As a great power, the U.S. has the capacity to influence others with its policies and capable of projecting its military power anywhere in the world. Its huge economic and military power has benefitted the U.S. in directing world's agendas whether through bilateral or multilateral strategy. In the Asian context, the U.S. policy in this region is traditionally constructed by bilateral relations and encouraged by economic motives (Noland 2009). The U.S. bilateral relation with Japan, China, and Korea are a clear example of the U.S. selective bilateral relation 
in Asia. Like China, U.S. strategic policy has changed gradually following the changing of perceptive threats.

The U.S. notorious defense and strategic policy since 1823 was the Monroe Doctrine. Monroe Doctrine is an American defense policy to defense American continent from European military campaign. Monroe Doctrine has determined American military campaign until the First World War. In relations of the Doctrine, the U.S. had insistently imposed the isolationism, unilateralism, and strict neutrality for decades. In World War II, U.S. strategic policy goal in Southeast Asia was to expel Japanese military expansion. Though security environment has been changed and lets America shift to a new 'doctrine' but the Doctrine itself is not entirely left (Gilderhus 2006). During the Cold War, the U.S. played the Containment Policy as its grand strategy against communism and Uni Soviet. Through this time, American soldiers had been sent far abroad to most of the parts of Asia region including Southeast Asia, South Asia, and East Asia. However, after the Vietnam War, U.S. has lost attention and systematically neglecting Southeast Asia (Ba 2009; Mauzy \& Job 2007). This negligence is the result of U.S. pessimistic view of the region and imbalance of its relations. During this time, the U.S. multilateral policy focused on transpacific relations.

U.S. multilateral relation with ASEAN was initiated in 1977 by opening Dialogue Relations channel (U.S. Mission to ASEAN 2017). Some issues covered in the dialogue including political, security, and "practical cooperation in commodities, market, and capital access, transfer of technology, development of energy resources, shipping, and food security" (ASEAN Secretariat 2017). Even though the U.S. has engaged as the Dialogue Partner of ASEAN, its attention to ASEAN was not well developed until the launched of ASEAN Regional Forum (ARF) in 1994. For the U.S., ARF is the strategic platform of its security architecture to maintain dominance in the Asia Pacific and possibly to check China's attitude toward the South China Sea.

After the 9/11, the U.S. turned its strategy to combat terrorist organizations notably the Al Qaida, and recently ISIS. In 2002 President Bush proclaimed U.S. new security directions which encompasses "the concepts of regime change, rogue state rollback, counter-proliferation, preventive warfare, and assertive democratization" (Dueck 2010). Bush's War on Terror policy quickly sparked a new world agenda. It then encouraged other states to bandwagoning Bush's policy. Southeast Asian nations and ASEAN also 
the joint U.S. led counter-terrorism campaign in the region. ASEAN has established a ministerial-level forum on transnational crimes to show its seriousness on the issue. In doing so, ASEAN works together with other parties such as U.S., China, India, and European Union. Nevertheless, Bush administration has put limited efforts to engage to ASEAN. Bush's terrorism heavy policy on Iraq, Afghanistan, and ASEAN is the strong indication of the U.S. limited engagement in Asia region (Lum et al. 2011; Oehler-Şincai 2014; Saunders 2013). Now that the communism is not a serious threat and $\mathrm{Al}$ Qaida is weakened, U.S. needs to reassess its security policy (Stimson 2012).

Considering the changing in security architecture in Southeast Asia, in the time of Obama administration, U.S. security policy has directed to a new horizon. Obama administration sees Asia particularly Southeast Asia region as a pivotal region which could influence Asia Pacific stability. It is argued that main attractions U.S. strategic policy shift towards the Asia Pacific is the rise of China, the economic potential of the region and potential threats of exporting terrorism. This led Obama to discharge strategic pivot or rebalancing policy. The pivot or rebalance policy emphasizes to deploy 60\% of U.S. military power in Asia Pacific region by 2020 (Evans 2013). By this rebalance policy what kind of interests that the U.S. would pursue? Six aspects characterize the formulation of this policy. It includes; strengthening U.S. alliance, improving relations with emerging powers (including China), increasing economic ties, employing multilateral approach, upholding universal values (human rights), and advancing U.S. military power (Campbell \& Andrews 2013; Limaye 2013). Some of the U.S. vital defense interests in Southeast Asia are to defend U.S. allies (Thailand and the Philippines) from foreign threats (possibly from China) and to make sure the implementation of freedom at high sea which in Southeast Asia is Malacca case (Stimson 2012). Therefore, looking at the crucial aspect of multilateralism, it suggests that the U.S. should strengthen its multilateral policy on Southeast Asia (Parameswaran 2013a).

\section{ASEAN Opions}

Reflecting Southeast Asia's changing security environment, the fundamental question is how U.S and China maneuver effects ASEAN and its members? ASEAN's position is relatively complex. Despite China and U.S, it stands among some other major powers, Japan and India. From a distance apart, Russia also has the influence to the region. These major 
powers have the tendency to extend their influence to ASEAN. On the other side, ASEAN needs to play balancing role and keep the stability in the region. Particularly ASEAN should carefully measure its policy towards U.S. and China's bilateral and multilateral policy strategy. Up to this day, China and the US have involved in some ASEAN multilateral forums. The most substantial forum for China -together with Japan and Republic of Korea- is ASEAN Plus Three. This forum is a hub for ASEAN multilateral cooperation with those three major partners. The cooperation themes include; transnational crime; trade and investment; finance; tourism; food, agriculture, fishery and forestry; minerals; small and medium enterprises; information and communication technology; energy; environment and sustainable development; networking of track II; poverty alleviation, promotion development of vulnerable groups; culture and people-to-people contact; education; science and technology; public health; and disaster management (ASEAN 2013). While the ASEAN and U.S. has formulated Plan of Action 2016-2020. The Plan covers three major aspects in ASEAN, the political and security, economic, and sociocultural (ASEAN 2015).

The U.S. and China bilateral policy towards members of ASEAN basically motivated by economic and security aspects. ASEAN-China Free Trade Area (ACFTA) boosts Chinese bilateral trade with ASEAN member states. Nevertheless, ASEAN suffers deficit setback in 2013 trade balance to the value of $\$ 45$ billion (Salidjanova, Koch-Weser, \& Klanderman 2015). Bilaterally, only Thailand and Malaysia gain surplus trade balance with China (Salidjanova et al. 2015). In the area of defense, some ASEAN member states turn to China as the provider of heavy armament. Thailand, for instance, relies on China's submarines to power up its Navy. Neglecting its Navy drill with the U.S., Thailand ordered three submarines from China all at once which worth around $\$ 1$ billion (Ehrlich 2015). Furthermore, Malaysia and China have a close bilateral relationship under the Comprehensive Strategic Partners framework. However, this strategic partnership did not go fast enough to meet its objective because it only increases defense diplomacy efforts but lost its practical basis (Bing 2015).

Table 1. Total Arms Imports of Selected ASEAN Countries

\begin{tabular}{|c|c|c|c|c|c|}
\hline \multirow{3}{*}{ Countries } & \multicolumn{4}{|c|}{ Arms Imports (in U.S.\$ billion) } & \multirow{3}{*}{ Total } \\
\hline & \multicolumn{2}{|c|}{2015} & \multicolumn{2}{|c|}{2016} & \\
\hline & China & U.S. & China & U.S. & \\
\hline
\end{tabular}




\begin{tabular}{|l|c|c|c|c|c|}
\hline Brunei & - & 36 & - & 36 & 72 \\
\hline Indonesia & 43 & 82 & 42 & 94 & 261 \\
\hline Philippines & - & 46 & - & 82 & 128 \\
\hline Malaysia & - & 4 & - & 6 & 10 \\
\hline Thailand & - & 27 & 77 & 46 & 150 \\
\hline Vietnam & - & - & - & - & 0 \\
\hline
\end{tabular}

(source compiled by author)

While comparing to the U.S., ASEAN enjoys trade surplus to the value of $\$ 22,1$ billion in the same year (ASEAN Secretariat 2015). Overall, in term of trade balance, China creates more fortune than the U.S. Bilaterally, the U.S. merely has single bilateral free trade with Singapore which was concluded in 2003 (Anonymous 2016). To cope with China's one step forward the U.S. in term FTA, the U.S. had boosted its bilateral relations with ASEAN member state through comprehensive agreement frameworks such as with Indonesia and Vietnam. Indonesia - U.S. comprehensive partnership covers the cooperation on democracy and civil society, education, security, environment, and energy ("United States-Indonesia Comprehensive Partnership" 2013). Under the scheme, Indonesia concluded a contract to acquire defense armaments, including Maverick missile and Apache which worth more than $\$ 720$ million ("United States-Indonesia Comprehensive Partnership" 2013). Indonesia is one example of ASEAN member state that is building its military capability. In general, other ASEAN members seem to look at the U.S. in advancing their defense capabilities. In doing so, ASEAN member states employing double tracks approach; importing from abroad and building home defense industries. For defense capability, ASEAN states still depend on major military producers especially, the U.S., Russia, China, and French.

Albeit the rising attention and worries on Chinese attitudes in the South China Sea and the possible clash with the U.S., ASEAN member states show split perception on China and the U.S. According to Pew Research Center survey in 2014, only Malaysia prefers China as an ally while other states see the U.S. as their ally (Wike, Stokes, Poushter, \& Oates 2014). In the same survey, it revealed that only Indonesia considered the U.S. as its ally and threat.

\section{Table 2. Selected ASEAN Countries View on Potential Ally and Threat}




\begin{tabular}{|l|l|l|}
\hline Indonesia & U.S. (28) & U.S. (25) \\
\hline Malaysia & China (27) & U.S. (26) \\
\hline Philippines & U.S. (83) & China (58) \\
\hline Thailand & U.S. (29) & Cambodia (11) \\
\hline Vietnam & U.S. (30) & China (74) \\
\hline
\end{tabular}

(source modified by author)

To this point, in the term of strategic perspective, it shows that ASEAN member states relatively feel more comfortable with the U.S. presence in the region and perceived China's as bring more to the region. It is believed that the attitude towards China is the reflection of concern on territorial disputes between China with Southeast Asian states, especially Vietnam and Philippines. This argument is confirmed by the Pew Research Center data of people concern on China's territorial disputes with its neighbors (China Power Team 2016). In contrast, in term of economic presence, ASEAN tends to welcome China rather than the U.S. Compare to other ASEAN's dialogue partners, ASEAN trade with China shows positive growth annually. But, this positive growth might indicate ASEAN dependency on China's products.

\section{Graphic 1. ASEAN Trade in Goods with Dialogue Partners in U.S. Dollar}

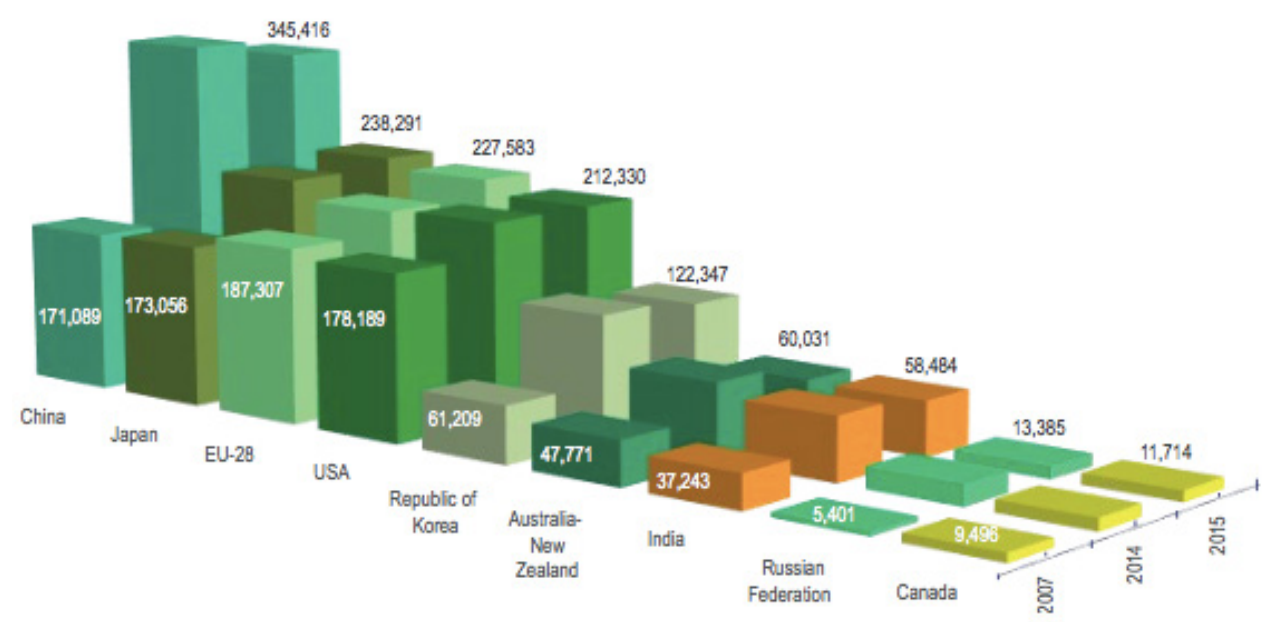

(source: AEC Chart book 2016 (ASEAN Secretariat 2016))

Graphic 2. ASEAN Trade in Goods with Dialogue Partners in 


\section{Percent Share}
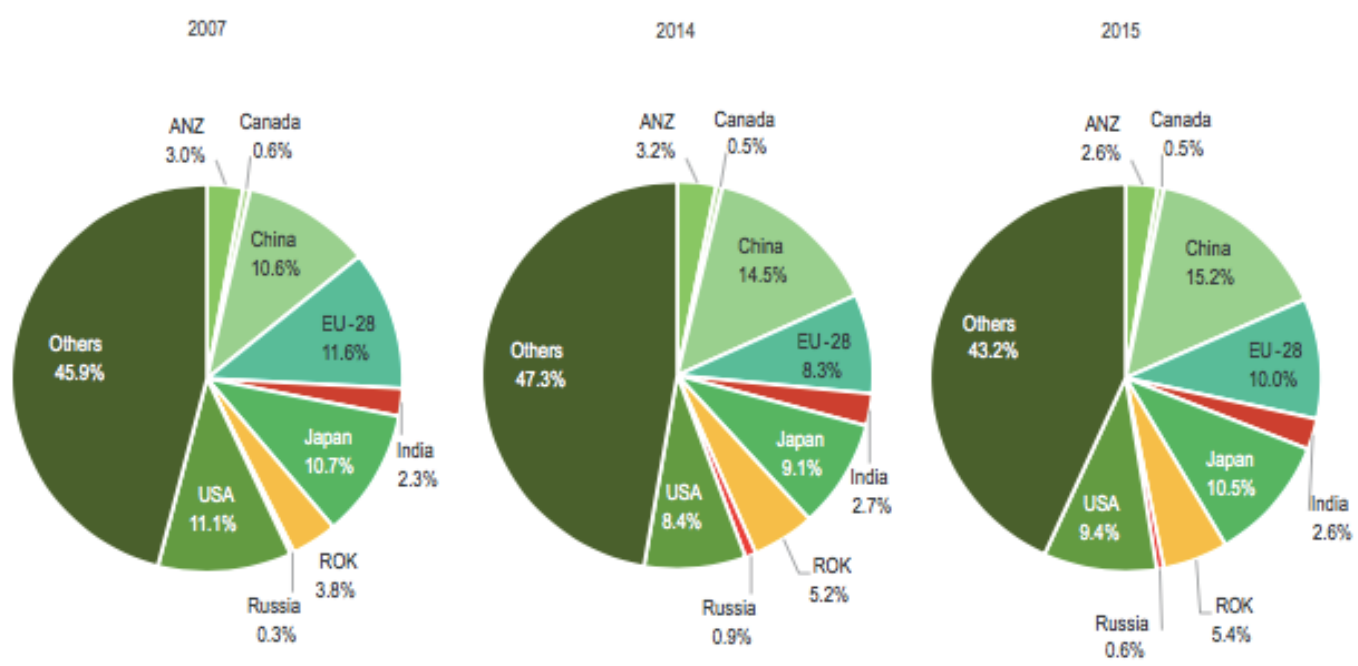

(source: AEC Chart book 2016 (ASEAN Secretariat 2016))

\section{Conclusion}

The first part of this paper has discussed the concept of bilateralism and multilateralism in brief. It followed by the discussion of both the U.S. and China bilateral and multilateral approaches towards ASEAN and its member states. The third part discussed and analyzed the impact of those major powers approaches to ASEAN and how should ASEAN behave to them. From those discussions, it can be concluded that the U.S. utilizes more on multilateral approach for defense cooperation with ASEAN while it tends to be more bilateral in its economic ties with ASEAN member states. For China, multilateral economic cooperation is the primary choice to approach ASEAN, while it builds more bilateral approach for defense cooperation. It also concluded that most of the multilateral approaches of the U.S. and China are in the framework of ASEAN multilateral forums. It means that ASEAN has the chance and capacity to highlight its agendas and policies. 


\section{References}

\section{Book}

ASEAN Secretariat. 2015. "ASEAN International Merchandise Trade Statistics Yearbook 2014” ASEAN Secretariat. Jakarta. doi:10.1017/ CBO9781107415324.004.

Dueck, Collin. 2010. Hard Line: The Republican Party and U.S. Foreign Policy since World War II. Princeton: Princeton University Press.

Hoon, Khaw Guat. 1977. “An Analysis of China's Attitudes Towards ASEAN, 1967-76." Singapore. Institute of Southeast Asia Studies.

\section{Journal and Online Journal}

Ba, Alice. 2009. "Systemic Neglect? A Reconsideration of US-Southeast Asia Policy." Contemporary Southeast Asia 31 (3): 369. doi:10.1355/ cs31-3a.

Bing, Ngeow Chow. 2015. "Comprehensive Strategic Partners but Prosaic Military Ties: The Development of Malaysia--China Defence Relations 1991-2015." Contemporary Southeast Asia: A Journal of International \& Strategic Affairs 37 (2): 269-304. doi:10.1355/cs37-2e.

Evans, Michael. 2013. "American Defence Policy and the Challenge of Austerity - Some Implications for Southeast Asia." Journal of Southeast Asian Economies 30 (2): 164-78. doi:10.1355/ae30-2d.

Gilderhus, Mark T. 2006. "The Monroe Doctrine: Meanings and Implications The Doctrine: Implications Meanings Conceived." Presidential Studies Quarterly 36 (1): 5-16. http://www.jstor.org/ stable/27552742.

Kuik Cheng-Chwee. 2005. "Multilateralism in China's ASEAN Policy: Its Evolution, Characteristics, and Aspiration." Contemporary Southeast Asia: A Journal of International \& Strategic Affairs 27 (1): 102-22. doi:10.1355/CS27-1F.

Kurlantzick, Joshua. 2006. "China’s Charm Offensive in Southeast Asia." Current History. 105 (692): 270-76.

Limaye, Satu P. 2013. "Southeast Asia in America's Rebalance to the Asia-Pacific." Southeast Asian Affairs 2013: 40-50. doi:10.1353/ saa.2013.0013.

Lum, Thomas, Ben Dolven, Mark E. Manyin, Michael F. Martin, and Bruce Vaughn. 2011. "Unites States Relations with the Association of Southeast Asian Nations (ASEAN)." Current Politics and Economics of South, Southeastern, and Central Asia 20 (2): 247-76. doi:10.1146/ annurev.polisci.6.121901.085546. 
Mauzy, Diane K, and Brian L Job. 2007. "U.S. Policy in Southeast Asia: Limited Re-Engagement after Years of Benign Neglect.” Asian Survey. 47 (4): 622-41. DOI: $10.1525 /$ as.2007.47.4.622

Ming-Te, H, and Ttt Liu. 2011. "Sino-US Strategic Competition in Southeast Asia: China's Rise and US Foreign Policy Transformation since 9/11.” Political Perspectives 5 (3): 96-119. http://www.politicalperspectives. org.uk/wp-content/uploads/Sino-US-strategic-competition1.pdf.

Morse, Julia C., and Robert O. Keohane. 2014. "Contested Multilateralism.” Review of International Organizations 9 (4): 385-412. doi:10.1007/ S11558-014-9188-2.

Noland, Marcus. 2009. "American Economic Relations with Asia." Asian Economic Policy Review 4 (2): 181-99. doi:10.1111/j.17483131.2009.01121.x.

Oehler-Şincai, Iulia Monica. 2014. "United States' ' Pivot' Towards AsiaPacific: Rationale, Goals and Implications for the Relationship With China." Knowledge Horizons - Economics 8 (1): 25-31.

Parameswaran, Prashanth. 2013a. “ The Power of Balance :' Advancing US-ASEAN Relations under the Second Obama Administration." The Fletcher Forum of World Affairs 37 (1): 123-34.

Pattiradjawane, René L, and Natalia Soebagjo. 2015. "Global Maritime Axis : Indonesia , China , and a New Approach to Southeast Asian Regional Resilience." International Journal of China Studies 6 (2): $175^{-85}$.

Ruggie, John Gerard. 1992. "Multilateralism; Anatomy of Institution.pdf." International Organization 46 (3): 561-98.

Thayer, Carlyle A. 2003. "China's 'New Security Concept' and Southeast Asia." Asia-Pacific Security: Policy Challenges, 89-107.

Wuthnow, Joel, Xin Li, and Lingling Qi. 2012. "Diverse Multilateralism: Four Strategies in China's Multilateral Diplomacy." Journal of Chinese Political Science 17 (3): 269-90. doi:10.1007/s11366-012-9202-6.

Yunhua, Cao. 2013. "What Kind of Policy towards Southeast Asia Does China Need for Its Peaceful Rise ?" Journal of Ritsumeikan Social Sciences and Humanities 5 (3): 41-55.

\section{Online Articles}

Anonymous. 2012. A New US Defense Strategy for a New Era: Military Superiority, Agility, and Efficiency: A Summary of the Findings of the Defense Advisory Committee. Washington: Stimson. [accessed on September, 18th 2016]

Anonymous. 2016. United States Trade Relations. https://ustr.gov/ 
trade-agreements/free-trade-agreements/singapore-fta. [accessed on September, 18th 2016]

ASEAN Secretariat. 2016. ASEAN Economic Community Chart book 2016. Jakarta. http://www.asean.org/asean-economic-community/. [accessed on September, 15th 2017]

2017. "Overview of ASEAN-United States Dialogue Relations." Jakarta. http://asean.org/storage/2012/05/Overview-of-ASEAN-US-Dialogue-Relations-August-2017.pdf [accessed on September, 15th 2017]

Cai, Peter. 2017. "Understanding China's Belt and Road Initiative." Sydney. https://www.lowyinstitute.org/sites/default/files/documents/ Understanding\%20China\%E2\%80\% 99s\%20Belt\%20and\%20 Road\%20Initiative_WEB_1.pdf. [accessed on September, 15th 2017]

Campbell, Kurt, and Brian Andrews. 2013. "Explaining the US 'Pivot' to Asia." Chatham House. London. http://www.kritisches-netzwerk. $\mathrm{de} / \mathrm{sites} / \mathrm{default} / \mathrm{files} /$ explaining_the_us_pivot_to_asia_-_ kurt_campbell_and_brian_andrews_-_the_asia_group_-august_2013_-_9_pages_o.pdf. [accessed on September, 17th 2016]

China Power Team. 2016. "How Are Global Views on China Trending?" China Power. https://chinapower.csis.org/global-views/. [accessed on September, 15th 2017]

Donahue, Kenneth S., and Therry Warin. 2009. "Multilateralism Cursed by Bilateralism: Japan's Role at IWC.” http://sandcat.middlebury. edu/econ/repec/mdl/ancoec/0904.pdf. [accessed on September, 15th 2016]

Ehrlich, Richard S. 2015. "Thailand Nears \$ 1 Billion Submarine Deal with China despite Exclusive US Military Training." The Washington Times. http://www.washingtontimes.com/news/2015/jul/7/thailandnears-1-billion-submarine-deal-with-china/?page=all. [accessed on September, 18th 2016]

Majid, Munir. 2012. "Southeast Asia between China and the United States," 21-35. http://www2.lse.ac.uk/IDEAS/Home.aspx. [accessed on September, 18th 2016]

Ministry of Foreign Affairs of the People's Republic of China. 2015. "Wang Yi Brought Forth a Ten-Point Proposal on China-ASEAN Cooperation." Ministry of Foreign Affairs of the People's Republic of China. http://www.fmprc.gov.cn/mfa_eng/zxxx_662805/t1286715. shtml. [accessed on September, 18th 2016]

Mitchell, Derek J (Ed). 2008. "The United States and Southeast Asia: Towards a Strategy for Enhanced Enggement.” A Conference Report of the CSIS Southeast Asia Initiative. Washington, DC. https://csisprod.s3.amazonaws.com/s3fs-public/legacy_files/files/media/ csis/pubs/o81208_mitchell_usandseasia-web.pdf. [accessed on September, 18th 2016] 
Parameswaran, Prashanth. 2013b. "Beijing Unveils New Strategy for ASEAN-China Relations.” China Brief XIII (21). https://jamestown. org/program/beijing-unveils-new-strategy-for-asean-chinarelations/. [accessed on September, 18th 2016]

Salidjanova, Nargiza, Iacob Koch-Weser, and Jason Klanderman. 2015; "China's Economic Ties with ASEAN : A Country-by-Country Analysis." United Stated - China Econimic and Security Review Commission. https://www.uscc.gov/sites/default/files/Research/China\%27s\%20 Economic\%20Ties\%20with\%20ASEAN.pdf. [accessed on September, 18th 2016]

Saunders, Phillip C. 2013. "The Rebalance to Asia: U.S.-China Relations and Regional Security." Strategic Forum. Institute for National Strategic Studies. doi:10.1111/j.1539-6975.2009.01318.x. [accessed on September, 18th 2016]

Stanley Foundation. 2003. "China and Southeast Asia." Policy Bulletin. Virginia. https://www.stanleyfoundation.org/publications/archive/ SPCo3Bpb.pdf. [accessed on September, 18th 2016]

Sutter, Robert G. 2005. "China's Rise in Asia - Promises, Prospects and Implications for the United States." Occasional Paper Series. http:// apcss.org/Publications/Ocasional\%20Papers/OPChinasRise.pdf. [accessed on September, 18th 2016]

U.S. Mission to ASEAN. 2017. "History of the U.S. and ASEAN Relations." https://asean.usmission.gov/our-relationship/policy-history/ usasean/. [accessed on Oktober, 15th 2017]

"United States-Indonesia Comprehensive Partnership." 2013. USTR. http://www.state.gov/r/pa/prs/ps/2013/10/215196.htm. [accessed on September, 18th 2016]

Vaughn, Bruce, and Wayne M. Morrison. 2006. "China - Southeast Asia Relations: Trends, İssues, and Implications for the United States." Congressional Research Service Report for Congress. https://fas.org/ sgp/crs/row/RL32688.pdf. [accessed on September, 18th 2016]

Wike, Richard, Bruce Stokes, Jacob Poushter, and Russ Oates. 2014. “Global Oppoosition to U.S. Surveillance and Drones, but Limited Harm to America's Image." http://www.pewglobal.org/files/2014/07/201407-14-Balance-of-Power.pdf. [accessed on September, 18th 2016]

Xinhua. 2013. "Li Raises Seven-Prolonged Proposal on Promoting ChinaASEAN Cooperation.” http://en.people.cn/90883/8420237.html. [accessed on September, 18th 2016]

Zubir,Mokhzani.2004."TheStrategicValueoftheStraitofMalacca."Analysis Paper, Maritime Institute of Malaysia, 1-19. http://www.aspirasindp.com/en/archive/ThestrategicvalueoftheStraitofMalacca.pdf. [accessed on September, 18th 2016] 